\section{GRASSLAND AND THE FEEDING OF LIVESTOCK}

$\mathrm{T}$ HE Nutrition Society held a meeting in Reading on July 20 which took the form of a symposium on "Grassland and the Feeding of Livestock", a subject of major importance in relation to the improvement both of the efficiency of animal production and of human nutritional status. Prof. H. D. Kay (Shinfield) was in the chair.

The first contributor was Dr. William Davies (Hurley). In an introductory paper he laid emphasis on the unstable nature of the grassland sward, ever changing in one direction or another in response to environmental changes. Following the destruction by man of the primeval forests which at one time covered the greater part of the present cultivable area of Great Britain and his subsequent agricultural efforts, several types of grassland of different botanical composition and of differing agricultural value developed. These can be conveniently divided into six major types, from the ryegrass-white clover pasture at the better end to the Molinia-Nardus pasture at the poorer. Far from stable, the poorer types can be improved under suitable managementincluding fertilizer treatment and grazing-or the better types can deteriorate when improperly managed. In one recorded trial, for example, fertilizer (calcium, nitrogen, phosphorus and potassium) treatment of a mainly Molinia hill pasture not only completely changed the botanical composition of the sward in a few years but also gave nearly ten times the yield of herbage (measured in lb. of dry weight per acre per year). Even grazing alone (without added fertilizer) of such a pasture more than doubled the yield of dry matter per acre in less than ten years. One of the effects of the fertilizer treatment was to bring in species, such as rough-stalked meadow grass and white clover, which were not present at all in the original sward. Good pasture management and knowledgeable fertilizer treatment not only give greatly increased yields of consumable grass, but also extend the normal grazing season into the autumn and spring.

Prof. W. Holmes (Wye) discussed the so-called law of diminishing returns in relation to the application of increasing quantities of nitrogenous fertilizers to crops and grass. For cereal and root crops the response curve is logarithmic ; thus, it has been found that for cereals each successive fertilizer dressing of $28 \mathrm{lb}$. of nitrogen per acre increases (on the average) the yield by 53 per cent of the previous increment. For leafy crops such as kale, the response is much greater, $28 \mathrm{lb}$. of nitrogen per acre increasing the yield by 78 per cent of the previous increment. For grassland the percentage response is greater still ; given suitable temperatures and water supply, it is almost linear up to an application of $300 \mathrm{lb}$. of nitrogen per вcre. Application of nitrogen also increases the efficiency with which water is used by the growing grass. A further factor arises when grass is grazed-namely, the return of nitrogen and other grass nutrients in the form of dung and urine; in effect, some of the fertilizer nitrogen is used more than once. Response to nitrogen treatment depends on climate, water supply, season and frequency of application. The situation is complicated since, owing to its content of legume, the normal clover grass sward derives directly or indirectly substantial quantities of nitrogen from the clover (of the order of 150-250 lb. of nitrogen per acre per year). Application of small amounts of fertilizer nitrogen in spring is very harmful to the clover and gives, therefore, poor total response; but heavy dressings give good responses in terms of total yields per acre; since grass is greatly stimulated though the clover is suppressed.

The capacity of grass to respond to large amounts of nitrogen is outstanding, and from the point of view of farm economics, very cheap cattle food may be produced by the skilful use of nitrogenous fertilizers. Provided there is also mastery of the technique of the utilization of grass by cattle, the results in animal production may be very profitable. This latter aspect was dealt with by Mr. A. S. Barker (London), who, in his paper on fertilizer nitrogen and milk production from grassland, emphasized the great importance of skilled management in making optimum use for grazing animals of the increased production of grass. Taking one year with another, the joint effect of fertilizer plus management can be measured in a dairy herd by the output of milk per cow per year or per acre of grassland per year. Given appropriate grassland and livestock management, it has been shown in a series of trials on farms that the application of increasing quantities of nitrogenous fertilizer from $23 \mathrm{Ib}$. of nitrogen per acre in steps of $23 \mathrm{lb}$. up to $115 \mathrm{lb}$. will increase the output of utilized feed at the rate of about 2-3 cwt. of 'starch equivalent' per acre for each increment of $23 \mathrm{lb}$. of nitrogen, and that at a practically linear rate. $\mathrm{Mr}$. Barker stated that, from the profit-and-loss point of view, at prices current during the past two years, $£ 1$ spent on fertilizer has given a considerably greate return in milk production than $£ 1$ spent on purchased food.

Mr. W. F. Raymond (Hurley) spoke on the measurement of pasture output. Most systems of pasture evaluation take little account of two of the main characteristics of pasture output-namely, that it is made up of a number of harvests in any one year, and that management in one year affects yields and persistence in subsequent years. Optimum management methods vary with different pastures. The total annual yield is of less importance practically than the distribution of that yield between different months of the year, while such herbage characters as persistence, palatability and winter greenness are also of major importance in relation to the evaluation of any particular sward for stock. Pasture investigation requires measurement of effective output from a pasture over a relatively short period; some techniques which have apparently been valid for assessing output over a whole grazing season are inadequate when applied to short grazing periods. As a yardstick, live-weight gains, at least over short periods, are not very helpful ; milk production is a rather more sensitive reflexion of pasture output than live-weight gains, but is even more dependent on management. Two methods of assessing pasture intake are being investigated, involving herbage eutting or frecal measurements with an indigestible tracer such as chromic oxide for determining the quantity of fæces voided, and analysis of the amount of lignin in the fæces to determine the digestibility of the herbage, with the aid of a 'fæcal index' based on indoor experiments on digestibility.

Dr. M. J. Head and Mr. J. A. F. Rook (Shinfield) discussed certain effects of spring grass on rumen digestion and the metabolism of the dairy cow, particularly in relation to hypomagnesæmia. Heavy 
dressings of nitrogenous fertilizer in early spring produce a rapid growth of succulent herbage containing a high percentage of crude protein. If this herbage is grazed by dairy cows as their sole diet, it provides an unbalanced ration containing excess of protein equivalent. The effect of the sudden change from the winter ration to such an unbalanced diet in the spring is not infrequently to induce severe hypomagnesæmia and 'tetany'.

Rumen fermentation of such spring herbage has been shown to lead to increased production of ammonia ; the ammonia is absorbed from the rumen into the blood stream and can be demonstrated in the portal vein and sometimes in the peripheral blood. This production of ammonia in the rumen can be depressed by feeding starch. Ammonia in the circulating blood may be toxic in relatively low concentrations.

Hypomagnesæmia in the cow in spring is due in part to the low availability to the animal of the magnesium in spring herbage, and in part to the relatively low daily intake of magnesium in the grass diet in comparison with the intake from winter feed. The hypomagnesæmia is most severe in those cows with the highest levels of ammonia in the blood. If the ammonia concentration in the rumen of a cow is artificially raised, the magnesium-level in the blood is depressed. On the other hand, low level of magnesium in the blood induced by feeding young spring grass may be raised again by feeding maize starch, which at the same time causes a drastic reduction in ammonia-levels in the rumen.

The final paper in this symposium, by Dr. W. A. McGillivray (Palmerston North, New Zealand) and Dr. S. Y. Thompson (Shinfield), was concerned with the influence of pasture on the vitamin $A$ and carotene in the milk of cows. Calculation shows that, in the average human diet in Britain, cows' milk contributes about 20 per cent of the daily requirements of vitamin A. Three factors influence the vitamin A content of cows' milk, as follows : stage of lactation -colostrum and very early lactation milk are richer in both carotene and vitamin $\mathbf{A}$ than milk secreted during the rest of the lactation period; hormonal influences- the thyroid plays a part in caroten $\theta$ metabolism in the cow; and feed of the cow-the major factor. The cow converts carotene inefficiently into vitamin A. Intake of carotene is, however, probably quite sufficient on pasture to produce butter with high vitamin A potency ; but on a winter diet this potency diminishes markedly. In New Zealand, where cows-predominantly Jerseys-are fed outdoors on pasture throughout the year, a uniformly high vitamin A potency in milk fat might be expected. In fact, the potency depends in large part on the botanical composition of the herbage, less carotene being absorbed and utilized on a pasture containing much clover than on one containing little clover. The tocopherol content of milk fat is likewise decreased on a high-clover pasture. There are probably two forms of carotene in blood plasma, on $\theta$ which contributes little to milk-fat-carotene levels and is associated with vitamin $A$ alcohol, and the other which is present on a carotene-containing diet and is associated with vitamin A ester and dietary fat in the chylomicrons, taken up directly by the mammary gland to contribute to the synthesis of milk fat.

Quickly growing, 'improved' pasture produces a number of metabolic disturbances in sheep and in cows in New Zealand. Muscular dystrophy is found in young sheep (though there is adequate tocopherol in the pasture). There seems to be an anti-vitamin D factor in pasture, producing rickets in young lambs. Bloat in cows is a serious problem in New Zealanddrenching the cows with oil appears to be an effective treatment. Facial eczema in sheep, associated with lush pasture, also causes serious losses in some years ; its cause is not yet understood.

Each paper in the symposium was followed by a short but lively discussion; from these discussions it is clear that two of the present urgent needs in relation to the feeding of farm livestock on pasture are : first, more knowledge of those constituents of rapidly growing herbage which at times upset the metabolic balance of grazing ruminants; and second, how such upsets can be most conveniently prevented in practice on the ordinary farm, without diminishing the advantages of modern methods for improving the efficiency of grassland production.

H. D. $\mathrm{K}_{\mathrm{AX}}$

\section{THE 1956 CAMBRIDGE SUMMER SCHOOL IN PHYSICAL CHEMISTRY}

$\mathrm{T}$ HE rate at which modern science advances continues to increase, and most scientists, though confining their activities within narrow channels, find themselves incapable of synchronizing with the acceleration. One way of contending with this situation is by means of the refresher course, where a small number of lecturers who have paid special attention to certain selected subjects give brief reviews on recent developments, stressing general theoretical principles rather than detailed experimental technicalities. With this object in mind, the Department of Physical Chemistry of the University of Cambridge has arranged summer schools, at intervals of three years, since the end of the Second World War.

This year's summer school, held during August 18-25, began with an inaugural lecture on Saturday night by the head of the Department, Prof. R. G. W. Norrish, who outlined briefly the history of the University of Cambridge and in particular of the origin and growth of its scientific departments. Prof. Norrish is particularly well qualified for such a lecture, being a Cambridge man in every sense of the word; he was born in the City, and, before entering the University, was educated at the Perse School, the ancient hall of which is now one of the most attractive features of his Department. The lecture, though full of fact, was interspersed with adequate humour, and helped to create an atmosphere of welcome to the 116 visitors who attended the school. The first real mingling of the visitors among themselves and with many Cambridge dons began in a garden party held on Sunday in the pleasant grounds of Sidney Sussex College.

The scientific course, which started on August 20, consisted of a course of fourteen lectures devoted to two broad topics, both of which are rapidly developing, namely, the applications of spectroscopy to chemical problems and the application of intermolecular force theory to the study of fluids. The first lecture was given by Prof. H. C. Longuet-Higgins on the nature of intermolecular forces and the properties of imperfect gases. Direct electrostatic, induction and dispersion forces play a part in determining intermolecular potential energies, and must be supple- 